\title{
Improvement of the functional properties of whey protein hydrolysate by conjugation with maltodextrin
}

Eve M. Mulcahy ${ }^{\mathrm{a}}$, Curtis W. Park ${ }^{\mathrm{b}}$, MaryAnne Drake ${ }^{\mathrm{b}}$, Daniel M. Mulvihill ${ }^{\mathrm{a}}$, James A. O’Mahony ${ }^{\text {a* }}$

\footnotetext{
${ }^{a}$ School of Food and Nutritional Sciences, University College Cork, Cork, Ireland

${ }^{b}$ Department of Food Science, Bioprocessing and Nutritional Sciences, Southeast Dairy

Foods Research Center, Raleigh, North Carolina State University, USA, 27695
}

*Corresponding author. Tel.: +353 214903625

E-mail address: sa.omahony@ucc.ie (J. A. O’Mahony) 
3 ABSTRACT

4

5 The impact of conjugation with maltodextrin on selected functional properties (i.e., solubility

6 and thermal stability) of intact whey protein isolate (WPI) and whey protein hydrolysate

7 (WPH) was determined. Conjugation of WPI and WPH (degree of hydrolysis 9.3\%) with

8 maltodextrin (MD) was achieved by heating solutions of 5\% WPI or WPH with 5\% MD,

9 initial $\mathrm{pH} 8.2$, at $90{ }^{\circ} \mathrm{C}$ for up to $24 \mathrm{~h}$. The WPH had $55.4 \%$ higher levels of available amino

10 groups compared with the WPI, which contributed to more rapid and extensive conjugation

11 of WPH-MD, compared with WPI-MD. WPI-MD and WPH-MD solutions heated for $8 \mathrm{~h}$ had

12 significantly higher $(P<0.05)$ protein solubility than the respective WPI and WPH heated

13 control solutions, in the $\mathrm{pH}$ range 4.0-5.0. Conjugation of WPI and WPH with MD enhanced

14 the stability to heat-induced changes, such as turbidity development, gelation or precipitation,

15 in the presence of $40 \mathrm{mM}$ added $\mathrm{NaCl}$.

16 


\section{Introduction}

The Maillard reaction was first described by the French biochemist, Louis-Camille Maillard, in 1912 and is initiated when the $\varepsilon$-amino groups of lysyl residues and the $\alpha$-amino groups of terminal amino acids in proteins condense with the carbonyl groups of reducing carbohydrates (Martins, Jongen, \& Van Boekel, 2000). The reaction pathways of the Maillard reaction at the intermediate and advanced stages are complex and involve polymerisations, cyclisations and enolisations to form a diverse mixture of compounds (Hodge, 1953). The Maillard reaction pathways and the compounds formed are dependent on many factors including temperature, time, $\mathrm{pH}$, water activity and the intrinsic properties of the proteins and carbohydrate (Liu, Ru, \& Ding, 2012). Several studies have reported that conjugation of carbohydrate to protein, at the early stages of the Maillard reaction, can improve the functionality of the protein (Davidov-Pardo, Joye, Espinal-Ruiz, \& McClements, 2015; Liu \& Zhong, 2015; Martinez-Alvarenga et al., 2014).

Whey protein ingredients are commonly used in foods to exploit their nutritional and functional properties. The incorporation of whey protein hydrolysates into food formulations is a growing area of interest as they can provide specialised nutritional support for those with particular physiological needs (Clemente, 2000). In some nutritional products, whey protein hydrolysates are primarily used to reduce antigenicity associated with the intact protein and to increase tolerance and digestibility of the proteins in milk protein sensitive consumers (Nnanna \& Wu, 2007). Protein hydrolysates are generally characterised by their degree of hydrolysis (DH), which expresses the number of peptide bonds cleaved as a percentage of the total number of peptide bonds available (Foegeding, Davis, Doucet, \& McGuffey, 2002).

40 Controlled hydrolysis of whey proteins alters the physicochemical functionalities, including 
the solubility, heat stability, viscosity, emulsifying and foaming properties (Singh \&

Dalgleish, 1998; Wijayanti, Bansal, \& Deeth, 2014).

During heating, particularly in high ionic strength environments, intact whey proteins

are prone to denaturation and aggregation which can results in physical destabilisations, manifested as increased turbidity, gelation or phase separation of formulated products containing intact whey protein. Ju, Otte, Madsen, and Qvist (1995) reported that limited hydrolysis of whey protein isolate (DH 2-7\%), using trypsin, prevented heat-induced gelation of a protein solution $\left(12 \%, \mathrm{w} / \mathrm{v}\right.$, protein) on heating at $80{ }^{\circ} \mathrm{C}$ for $30 \mathrm{~min}$ at $\mathrm{pH} 3$ and 7 ; the low level of enzymatic hydrolysis liberated peptides with a lower molecular mass and less secondary structure than the intact proteins which limited heat-induced aggregation and gelation. However, whey protein hydrolysates can be susceptible to destabilisation when heated due to the exposure of buried hydrophobic residues and/or release of specific peptides that promote peptide-peptide and peptide-protein aggregation (Adjonu, Doran, Torley, \& Agboola, 2013; Creusot \& Gruppen, 2007a).

There is an increasing global demand for hydrolysed whey protein ingredients; however, hydrolysis of whey proteins may result in impairment of their functional properties (Dairymark, 2012; Smithers, 2008). O'Regan and Mulvihill (2013) reported that conjugation of sodium caseinate hydrolysates (DH 6, 13 or 48\%) with maltodextrin conferred improved emulsion stability under accelerated shelf life testing conditions $\left(7 \mathrm{~d}\right.$ at $\left.45^{\circ} \mathrm{C}\right)$ and enhanced protein solubility (by $\sim 10-50 \%$ ) at $\mathrm{pH} 4.0-5.5$ compared with the unconjugated sodium caseinate hydrolysates. It appears that there are no reports published on the functional properties of conjugated whey protein hydrolysates, or the influence of hydrolysis of whey protein on the extent of Maillard-induced conjugation. The present study focused on the influence of conjugation on selected functionalities (i.e., solubility and solution clarity/stability to heating with added salt) of intact and hydrolysed whey proteins. A reaction 
66 time course of up to $24 \mathrm{~h}$ was chosen for the study as it is beneficial to limit the progression

67 of the Maillard reaction as conjugation occurs at the early stages of the Maillard reaction and

68 advanced Maillard reaction products may cause off-flavours, loss of nutritional value, protein

69 crosslinking and generation of potentially toxic compounds (Martins et al., 2000).

70 Furthermore, the progression of conjugation of whey protein with maltodextrin was

71 monitored to assess if conjugation was impacted by the physical state of the whey protein

72 (i.e., intact or hydrolysed).

73

\section{Material and methods}

\subsection{Materials}

Whey protein isolate (WPI; produced by ultrafiltration and microfiltration) and whey protein hydrolysate (WPH; produced from the WPI) were obtained from Carbery Food Ingredients (Ballineen, Cork, Ireland). Protein content of the samples was determined using the Kjeldahl method as outlined in AOAC (1995), using nitrogen to protein conversion factors of 6.38 and 6.46 for WPI and WPH, respectively (Anand, Ward, Froehner, Brody, \& Schroeder, 2002). Ash content was determined by heating samples at $500{ }^{\circ} \mathrm{C}$ until a white ash was obtained (AOAC, 1995). Lactose was determined as described by Indyk, Edwards, and Woollard (1996) with minor modifications as detailed by Mulcahy, Mulvihill, and O’Mahony 86 (2016). Maltodextrin with a dextrose equivalent value of 17 (MD17) containing 0.1\% ash and 4.0\% moisture was obtained from Corcoran Chemicals Ltd. (Dublin, Ireland). All other reagents and chemicals were procured from Sigma-Aldrich (Tallaght, Ireland) unless otherwise stated. 
Size exclusion chromatography (SEC) was carried out as described by O'Loughlin et al. (2013) to determine the molecular mass distribution profile of the proteins and peptides in the WPI and WPH.

96

\subsection{Preparation of protein-carbohydrate conjugate solutions}

98

Blends of either WPI or WPH (5\%, w/v, protein) and MD17 (5\%, w/v, carbohydrate),

100 were added to ultrapure water and allowed to solubilise for $2 \mathrm{~h}$, at $22{ }^{\circ} \mathrm{C}$, with low speed magnetic stirring. The solutions (WPI/WPH-MD17) were adjusted to $\mathrm{pH} 8.2$ with $0.5 \mathrm{~N} \mathrm{KOH}$ and allowed to hydrate for $18 \mathrm{~h}$ at $4{ }^{\circ} \mathrm{C}$, before being readjusted to $\mathrm{pH} 8.2$ with $0.5 \mathrm{~N} \mathrm{KOH}$ at $22{ }^{\circ} \mathrm{C}$. The conjugated protein solutions were prepared according to the method of Mulcahy et al. (2016); briefly, aliquots $(250 \mathrm{~mL})$ of each solution were placed in $500 \mathrm{~mL}$ screwcapped, glass, conical flasks and heated at $90{ }^{\circ} \mathrm{C}$ for up to $24 \mathrm{~h}$ in a pre-equilibrated, shaking water bath. Samples were removed after heating for 3, 5, 8 and $24 \mathrm{~h}$ and cooled immediately in iced water and stored at $4{ }^{\circ} \mathrm{C}$ for further analysis. Control solutions of either WPI or WPH (5\%, w/v, protein) were also prepared, heated and sampled as described above.

\section{Determination of degree of hydrolysis and available amino groups}

The degree of hydrolysis (the number of peptide bonds cleaved enzymatically and expressed as a percentage of the original number of peptide bonds) of the WPH ingredient

114 and the available amino groups (AAG) of all unheated and heated WPI/WPH and WPI/WPH-

115 MD17 solutions were quantified by the ortho-phthalaldehyde (OPA) method as described by 
116 Nielsen, Petersen, and Dambmann (2001) with minor modifications as described by Mulcahy

117 et al. (2016).

118

$1192.5 \quad$ Determination of lysinoalanine

120

121

The level of lysinoalanine (LAL) in unheated and heated WPI/WPH and WPI/WPH-

MD17 solutions was quantified by reversed phase ultra-performance liquid chromatography

(Acquity H Class, Waters Corporation, Milford, MA, USA). LAL was extracted as described

by Calabrese, Mamone, Caira, Ferranti, and Addeo (2009) with minor modifications.

125

Samples were not derivatised prior to analysis and the acid hydrolysate was diluted 1:10 with

HPLC grade water. Injections were made onto a Waters Acquity HSS T3 C18 column (1.7

127 $\mu \mathrm{m}, 2.1 \times 100 \mathrm{~mm}$ ) at a flow rate of $0.5 \mathrm{~mL} \mathrm{~min}^{-1}$ and maintained at $40{ }^{\circ} \mathrm{C}$. The isocratic mobile phase consisted of $0.1 \%$ formic acid in water. Detection was performed was a single quadrupole mass spectrometer (SQ Detector 2, Waters Corporation) in ES+ mode with the

130 following settings: capillary voltage $0.35 \mathrm{~V}$, sampling cone $38 \mathrm{~V}$, source temperature $150{ }^{\circ} \mathrm{C}$,

131 desolvation temperature $650{ }^{\circ} \mathrm{C}$, desolvation gas flow $1200 \mathrm{~L} \mathrm{~h}^{-1}$ and LAL was quantified using the monovalent charged ion 234.04 in selective ion monitoring mode. An 8 point standard curve was constructed ranging from $25 \mu \mathrm{g} \mathrm{L} \mathrm{L}^{-1}$ to $5 \mathrm{mg} \mathrm{L}^{-1}$ for quantification.

\subsection{Fluorescence of advanced Maillard products} measured using a BCA assay kit (Fisher Scientific, Ballycoolin, Dublin, Ireland). The 
140 fluorescence of advanced Maillard products $\left(\mathrm{F}_{\mathrm{AMP}}\right)$ was expressed as relative fluorescence

141 units per gram of protein ( $\mathrm{RFU} \mathrm{g}^{-1}$ protein).

142

143 2.7. Measurement of colour

The colour of the unheated and heated WPI/WPH and WPI/WPH-MD17 solutions

146 (5\%, w/v, protein) was determined as described by Mulcahy et al. (2016) using a pre-

147 calibrated colorimeter (Minolta Chroma Meter CR-400, Minolta Ltd., Milton Keynes, UK).

148 Colour was expressed as the Commission Internationale de l'Eclairage (CIE) L* colour

149 chromaticity coordinate.

150

151

\subsection{Protein solubility}

152

Protein solubility of WPI/WPH and WPI/WPH-MD17 solutions heated at an initial

$154 \mathrm{pH}$ of 8.2 at $90^{\circ} \mathrm{C}$ for $8 \mathrm{~h}$ and their respective unheated controls was determined in the $\mathrm{pH}$ range 2-8 using the method described by Mulcahy et al. (2016).

156

2.9. Effect of heating with added $\mathrm{NaCl}$ on physicochemical properties and microstructure

The development of turbidity in solutions was determined based on the method of Liu and Zhong (2015) and Mulcahy et al. (2016). Solutions of unheated WPI/WPH and WPI/WPH-MD17 (2.5\%, w/v, protein, $\mathrm{pH} 6.8$, with $40 \mathrm{mM}$ added $\mathrm{NaCl})$ were prepared as controls and each solution $(2.5 \mathrm{~mL})$ was subsequently heated at $85^{\circ} \mathrm{C}$, in $7 \mathrm{~mL}$ polycarbonate tubes (length, $47 \mathrm{~mm}$; external diameter, $20 \mathrm{~mm}$; wall thickness, $2 \mathrm{~mm}$ ), for $10 \mathrm{~min}$ in a water

164 bath before the tubes were cooled by immersion in iced water for $5 \mathrm{~min}$. The solutions of 
165 WPI/WPH and WPI/WPH-MD17 previously heated at initial $\mathrm{pH} 8.2$, for $8 \mathrm{~h}$ at $90{ }^{\circ} \mathrm{C}$ (i.e.,

166 conditions required to achieve conjugation) were adjusted to $\mathrm{pH} 6.8$, diluted to $2.5 \%$, w/v,

167 protein and $40 \mathrm{mM} \mathrm{NaCl}$ was added before being heated at $85^{\circ} \mathrm{C}$ for $10 \mathrm{~min}$ (treated in the

168 same manner to that described above). The turbidity of the solutions was compared by

169 measuring the transmission of light at $400 \mathrm{~nm}$ through the sample in a spectrophotometer

170 (Varian Inc., Palo Alto, CA, USA.) and by assessing and recording the changes in visual appearance using photography. Turbidity results are reported as the percentage difference in transmission of light between the respective control solutions and those heated at $85{ }^{\circ} \mathrm{C}$ for $10 \mathrm{~min}$.

Microstructural analysis of the solutions containing $40 \mathrm{mM}$ added $\mathrm{NaCl}$ that were heated (at $\mathrm{pH} 6.8$, at $85^{\circ} \mathrm{C}$, for $10 \mathrm{~min}$ ) and their respective controls, as described previously, was performed using an Olympus Fluoview FV1000 confocal laser scanning microscope (Olympus Corporation, Tokyo, Japan). Samples were vortexed (5 s) before protein was fluorescently labelled with Fast Green FCF dye $(0.1 \%$, w/v) as described by Drapala, Auty, Mulvihill, and O’Mahony (2015). Visualisation of protein in the solutions (10 $\mu \mathrm{L})$ was carried out in glass bottom micro-well dishes using a He-Ne laser operating at an excitation wavelength of $633 \mathrm{~nm}$. The observations were performed using 100× oil immersion objectives. At least three specimens of each sample were observed to obtain representative micrographs of samples.

\subsection{Statistical analysis}


190

191

192

193

194

195

196

197

198

199

200

201

202

203

204

205

206

207

208

209

210

211

212

213

214

the significance of differences among the mean values using the Minitab 16 (Minitab Ltd, Coventry, UK, 2007) statistical analysis package and the level of significance was determined at $P<0.05$.

\section{Results and Discussion}

\subsection{Compositional characterisation of WPI and WPH}

Compositional analysis of the WPI and WPH showed that both ingredients had generally similar protein and ash contents but that the lactose content of the WPH was higher than that of the WPI (Table 1) and the degree of hydrolysis (9.3\%) of the WPH was classified as low (Panyam \& Kilara, 1996). Size exclusion chromatography profiles of the WPI showed that $28.0 \%$ of protein had a molecular mass $>20 \mathrm{kDa}$, which was attributed to the presence of minor whey proteins such as bovine serum albumin (BSA; $66 \mathrm{kDa})$, lactoferrin (78-86 kDa), immunoglobulins (55-59 kDa) or whey protein oligomers/aggregates (Table 1). The majority $(50.5 \%)$ of protein in the WPI had a molecular mass in the range $10-20 \mathrm{kDa}$; a range that represents the major native whey protein fractions $\beta$-lactoglobulin $(\beta-\lg ; 18.4 \mathrm{kDa})$ and $\alpha-$ lactalbumin ( $\alpha$-lac, $14.2 \mathrm{kDa})$. The remaining material (21.5\% of protein) had a molecular mass between $0-10 \mathrm{kDa}$, which is likely due to the presence of glycomacropeptide $(\sim 7.5$ kDa; Sharma, Rajput \& Mann, 2013), small amounts of proteose peptones or other low molecular mass protein components (Saint-Sauveur, Gauthier, Boutin, \& Montoni, 2008). The WPH had $12.0 \%$ of protein with molecular mass $>20 \mathrm{kDa}$ that could be attributed to the low abundance of high molecular mass whey proteins (as described above) or protein/peptide oligomers/aggregates formed during the production of the protein hydrolysate (Nielsen, 1997; O'Loughlin et al., 2013). The WPH had 24.2\% of protein in the 
molecular mass range 10-20 kDa corresponding mainly to residual unhydrolysed $\beta$-lg and $\alpha$ -

216 lac. The remaining material (61.9\%) had a molecular mass range of $0-10 \mathrm{kDa}$ that may be

217 associated with peptides and amino acids. A small amount (1.8\%) of insoluble material was

218 present in the WPH, which is likely due to the formation of high molecular mass aggregated

219 whey protein material during heat treatment applied to the protein solution prior to hydrolysis

220 or during the thermal inactivation of proteolytic enzymes in the production of WPH

221 (O’Loughlin et al., 2013).

222

\subsection{Change in available amino groups on heating}

Only the $\alpha$-amino group of a terminal amino acid or the $\varepsilon$-amino group of lysyl

residues can partake in the Maillard reaction, which amounts to 16 and 13 potential available conjugation sites per $\beta$-lg and $\alpha$-lac molecule, respectively (Chevalier, Chobert, Popineau,

Nicolas, \& Haertlé, 2001). During enzymatic hydrolysis, proteins are broken down into peptides and free amino acids (as a result of cleavage of the peptide bonds) which can generate new $\alpha$-amino groups and expose previously buried lysyl residues. The total number of amino groups available to react with the carbonyl groups of reducing sugars was $55.4 \%$ higher in the WPH solution than in the WPI solution, giving the WPH a greater propensity to undergo Maillard-induced changes during heating. The physical state of the protein affected the rate and extent of the reduction of available amino groups (AAG) during heating (Fig. 1). The level of AAG in the WPI control solution did not decrease on heating at $90{ }^{\circ} \mathrm{C}$ for $24 \mathrm{~h}$ but there was a $15 \%$ reduction in AAG for the WPH control solution under the same heating conditions. This decrease in AAG for the WPH solution may have been due to heat-induced interaction between proteins and lactose, as the WPH contained more lactose than the WPI 
also cause blockage of the AAG within the WPI/WPH solutions (Creusot \& Gruppen, 2007a).

The WPI/WPH solutions containing MD17 had the greatest reduction in AAG compared with the respective WPI/WPH controls (without MD17). In the WPI-MD17 solution, $24 \mathrm{~h}$ of heating was required for the AAG to reduce by $3 \%$ compared with a $26 \%$ reduction in AAG for hydrolysed WPH-MD17 solutions after the same treatment. The greatest reduction in AAG groups for WPH-MD17 solutions occurred during the first $8 \mathrm{~h}$ (20.9\% reduction in AAG) of heating, with a considerably smaller, further decrease $(5.1 \%)$ in AAG occurring between 8 and $24 \mathrm{~h}$ of heating. At $8 \mathrm{~h}$ of heating there was a $2 \%$ reduction in AAG on conjugation of WPI-MD17 compared with a $21.1 \%$ reduction on conjugation of WPH-MD17.

\subsection{Development of lysinoalanine on heating}

The presence of lysinoalanine (LAL) in protein solutions has been reported to be responsible for protein crosslinking leading to impairment of functional properties and loss of nutritional value (Pellegrino, Van Boekel, Gruppen, Resmini, \& Pagani, 1999). The WPI solution heated for $8 \mathrm{~h}$ at $90^{\circ} \mathrm{C}$ had a high level of LAL (178.6 mg $100 \mathrm{~g}^{-1}$ protein) compared with the unheated WPI solution (14.1 mg $100 \mathrm{~g}^{-1}$ protein). The level of LAL in the heated WPI-MD17 solution $\left(58.8 \mathrm{mg} 100 \mathrm{~g}^{-1}\right.$ protein $)$ at $8 \mathrm{~h}$ was significantly $(P<0.05)$ lower than in the heated WPI solution. However, the level of LAL in the heated WPH solution (100.1 $\mathrm{mg} 100 \mathrm{~g}^{-1}$ protein) at $8 \mathrm{~h}$ was not significantly $(P>0.05)$ different from that in the heated WPH-MD17 solution (98.2 mg $100 \mathrm{~g}^{-1}$ protein) at $8 \mathrm{~h}$. Heat treatment of proteins, especially at alkaline $\mathrm{pH}$, can lead to the formation of LAL by $\beta$-elimination of seryl or cystyl residues

264 to form the intermediate dehydroalanine, which can then react with the $\varepsilon$-amino group of 
265 lysine (Calabrese et al., 2009). As the $\varepsilon$-amino group of lysine can also be consumed by the

266 covalent attachment of maltodextrin to protein during the Maillard reaction (Fig. 1),

267 competition for the $\varepsilon$-amino reaction sites is likely to result in lower levels of LAL in heated 268 WPI/WPH-MD17 solutions compared with the heated WPI solution.

\section{4. $\quad$ Change in $\mathrm{pH}$ on heating}

Preliminary trials showed that heating of the WPI/WPH-MD17 solutions at an initial $\mathrm{pH}$ of 6.8 , at $90^{\circ} \mathrm{C}$ resulted in gelation or physical destabilisation and separation of the samples; therefore an initial $\mathrm{pH}$ of 8.2 was selected to minimise these intermolecular proteinprotein/peptide interactions. The $\mathrm{pH}$ of the WPI control solution decreased slightly but not significantly $(P>0.05)$ during heating $\left(90^{\circ} \mathrm{C}\right.$ for up to $\left.24 \mathrm{~h}\right)$ but the $\mathrm{pH}$ of the WPI-MD17 solution decreased significantly $(P<0.05)$ from $\mathrm{pH} 8.2$ to 7.4 on heating for $24 \mathrm{~h}$ (Fig. 2). The decrease in $\mathrm{pH}$ can be attributed to the production of organic acids (i.e., formic or acetic acid) during the intermediate stages of the Maillard reaction and the consumption of charged amino acids, such as the basic amino acid lysine (Martins et al., 2000). The WPH control solution decreased from $\mathrm{pH} 8.2$ to 7.4 after $24 \mathrm{~h}$ of heating, which is likely to be due to the reaction of the proteins/peptides with innate lactose present in the WPH during heating (Berg \& Van Boekel, 1994). The pH of the WPH-MD17 solution decreased from 8.2 to 6.6 after $24 \mathrm{~h}$ of heating indicating that the Maillard reaction progressed at a greater rate and to a greater extent than in all other solutions. The decrease in $\mathrm{pH}$ of the WPI/WPH-MD17 solutions was most rapid during the first $8 \mathrm{~h}$ of heating.

\subsection{Colour development}



and is generally attributed to the formation of nitrogenous polymers and co-polymers

292 (Friedman, 1996). Photographs of colour development in all solutions throughout the $24 \mathrm{~h}$ heating time course are shown in Fig. 3. The L* value of the WPI solution decreased from 56.8 to 48.6 units after $24 \mathrm{~h}$ of heating at $90{ }^{\circ} \mathrm{C}$, most likely due to reaction of the whey proteins with innate lactose $(0.4 \%)$ present in the WPI ingredient on heating resulting in low levels of browning (associated with the Maillard reaction). The $\mathrm{L}^{*}$ value of the WPI-MD17 solution decreased from 56.8 to 34.9 units as brown colour developed after 24 h of heating at $90{ }^{\circ} \mathrm{C}$; however, there was only a low corresponding reduction of AAG (3.0\%) in the heated WPI-MD17 solution indicating low levels of conjugation were achieved even as the production of colour compounds associated with the advanced stages of the Maillard reaction was evident. The $\mathrm{L}^{*}$ value of the WPH solution decreased from 49.0 to 41.4 units while that of the WPH-MD17 solution decreased from 49.6 to 30.0 units after $24 \mathrm{~h}$ of heating with a concomitant development of brown colour. The production of coloured compounds in the WPH/WPI-MD17 solutions at $8 \mathrm{~h}$ of heating was limited compared with the solutions at $24 \mathrm{~h}$ of heating; at heating times $>8 \mathrm{~h}$, there were significant decreases $(P<0.05)$ in the $\mathrm{L}^{*}$ value for all solutions containing maltodextrin, with an accompanying increase in brown colour being evident.

\subsection{Fluorescence of advanced Maillard products}

To maximise the conjugation of proteins/peptides with maltodextrin and minimise the progression of the Maillard reaction into the later stages, the fluorescence of advanced Maillard products $\left(\mathrm{F}_{\mathrm{AMP}}\right)$ was monitored throughout the $24 \mathrm{~h}$ heating time course (Fig. 4). All the unheated solutions of WPI/WPH and WPI/WPH-MD17 had low levels of F AMP $_{\text {(2.4-3.5 }}$ 
315 relative fluorescence units; RFU) and the WPI solution did not significantly $(P>0.05)$

316 increase in $\mathrm{F}_{\mathrm{AMP}}(3.7 \mathrm{RFU})$ after $24 \mathrm{~h}$ of heating at $90^{\circ} \mathrm{C}$.

317 There was relatively limited development of $\mathrm{F}_{\text {AMP }}$ in the WPI-MD17 solution (13.0

318 RFU) after heating for $24 \mathrm{~h}$. The $\mathrm{F}_{\mathrm{AMP}}$ increased linearly $\left(\mathrm{R}^{2}>0.98\right)$ as a function of heating

319 time for the WPH and WPI/WPH-MD17 solutions. The level of $\mathrm{F}_{\text {AMP }}$ was significantly $(\mathrm{P}<$

320 0.05) higher in both the WPH (36.1 RFU) and the WPH-MD17 (91.7 RFU) solutions when

321 compared with the WPI (3.6 RFU) and WPI-MD17 (13.0 RFU) solutions, respectively, after

$32224 \mathrm{~h}$ of heating. Similar results were reported by Da Silva Pinto et al. (2011) who showed that

323 heating solutions containing mixtures of $\beta$ - $\lg$ and glucose (at an initial $\mathrm{pH}$ of 7 , at $90{ }^{\circ} \mathrm{C}$ for

$32424 \mathrm{~h}$ ) resulted in a threefold increase in the quantity of $\mathrm{F}_{\mathrm{AMP}}$ in the solutions. The WPI/WPH-

325 MD17 solutions after $8 \mathrm{~h}$ of heating which were found to have significantly $(P<0.05)$ lower

326 levels of $\mathrm{F}_{\mathrm{AMP}}(6.1$ and $31.7 \mathrm{RFU})$ and colour development than those heated for $24 \mathrm{~h}$ and

327 were thus chosen for assessment of functionality.

328

329

\subsection{Protein solubility}

330

331

Unheated WPI and WPI-MD17 solutions had high protein solubility $(>88.0 \%)$ at $\mathrm{pH}$

332

2.0-8.0 with the lowest protein solubility for the unheated WPI and WPI-MD17 solutions

333 occurring near the isoelectric point of the whey proteins (Fig. 5A). The protein solubility of

334 the WPI solution previously heated at an initial $\mathrm{pH}$ of 8.2 , at $90{ }^{\circ} \mathrm{C}$ for $8 \mathrm{~h}$ was significantly

335 lower $(P<0.05)$ than that of the corresponding unheated WPI solution in the $\mathrm{pH}$ range $3.0-$

3365.5 , with the lowest protein solubility (24.9\%) at $\mathrm{pH} 4.0$ for the heated WPI solution,

337 compared with a solubility of $88 \%$ for the unheated WPI solution at the same $\mathrm{pH}$. The

338 decrease in solubility of whey protein after heating is attributed to either unfolding of protein

339 structure, which exposes hydrophobic/sulphydryl reactive sites, resulting in greater protein- 
protein interactions occurring or heat induced crosslinking of the protein molecules (Mulcahy et al., 2016). In the $\mathrm{pH}$ range 3.0-5.0, the WPI-MD17 solution that was heated for $8 \mathrm{~h}$ at 90 ${ }^{\circ} \mathrm{C}$ had significantly higher $(-<0.05)$ protein solubility than the WPI solution heated without maltodextrin. The greatest improvement was observed at $\mathrm{pH} 3.5$, where the heated WPI solution had a protein solubility of just $26.7 \%$ compared with the heated WPI-MD17 solution that had a protein solubility of 50.7\%, while both the heated WPI and WPI-MD17 had lowest protein solubility of 24.9 and $30.1 \%$, respectively, at $\mathrm{pH} 4.0$.

4.0-4.5, which was lower than the protein solubility of the unheated WPI in the same $\mathrm{pH}$ range (Fig. 5B). This could be attributed to the exposure of buried hydrophobic residues and/or release of specific peptides during hydrolysis that promote peptide/protein-peptide aggregation (Creusot \& Gruppen, 2007b). The heated WPH solution $\left(8 \mathrm{~h}\right.$ at $\left.90{ }^{\circ} \mathrm{C}\right)$ had a similar protein solubility across the $\mathrm{pH}$ range $2.0-8.0$ to the unheated WPH solution. Peptides produced by enzymatic hydrolysis have smaller molecular masses and less secondary structure than intact proteins, which can limit heat-induced changes (Chobert, Bertrand-Harb \& Nicolas, 1988). At $\mathrm{pH} 4.0-4.5$, the protein solubility of the heated WPH-MD17 solution increased significantly $(P<0.05)$ by $5.6 \%$ compared with that of the heated WPH solution (75.3\% protein solubility). This increase in protein solubility of solutions of the heated WPHMD17 conjugate compared with solutions of WPH heated $\left(8 \mathrm{~h}\right.$ at $\left.90{ }^{\circ} \mathrm{C}\right)$ without MD17 and solutions of WPI conjugated with $\operatorname{MD} 17\left(8 \mathrm{~h}\right.$ at $\left.90{ }^{\circ} \mathrm{C}\right)$ can be attributed to enhanced

360 hydration of the protein due to the steric hindrance between the protein molecules provided by the attachment of the bulky dextran molecules.

362 solutions containing added $\mathrm{NaCl}$ 
$367 \sim 1 \mu \mathrm{m}$ ) were present in the unheated WPI and WPH solutions (Fig. 6; 1A and 4A) and no differences were observed between the unheated WPI/WPH solutions and the WPI/WPH solutions containing MD17 (data not shown). Once the previously unheated WPI solution (with $40 \mathrm{~mm} \mathrm{NaCl}$ added subsequently) was heated at $85^{\circ} \mathrm{C}$, at $\mathrm{pH} 6.8$, for $10 \mathrm{~min}$, the protein formed a turbid, continuous gel network (Fig. 6; 1B). The presence of $\mathrm{NaCl}$ in protein solutions can decrease the inter-protein charge repulsions which can lead to increased protein-protein interactions, protein aggregation and gel formation (Ryan et al., 2012). The WPI solution that was heated for $8 \mathrm{~h}$ at $90{ }^{\circ} \mathrm{C}$ showed an increase in the number of small dense protein aggregates $(<\sim 1 \mu \mathrm{m})$ when compared with the unheated WPI solution (Fig. 6; 2A). This previously heated WPI solution $\left(8 \mathrm{~h}\right.$ at $\left.90{ }^{\circ} \mathrm{C}\right)$ increased in turbidity by $56.4 \%$ compared with the pre-heated control and large protein aggregates $(\sim 30-50 \mu \mathrm{m})$ formed but the solution did not gel when it was subsequently had $40 \mathrm{mM} \mathrm{NaCl}$ added and received a further heat treatment $\left(10 \mathrm{~min}\right.$ at $85^{\circ} \mathrm{C}$; Fig. 6 ; 2B). This indicated that pre-heated intact whey proteins were less susceptible to further heat-induced structural changes and gelation compared with untreated whey proteins on further heat treatment in the presence of added salt (Fig 6; 1B). Similar results were reported by Ryan et al. (2012) who showed that soluble whey protein aggregates formed by heating WPI for $10 \mathrm{~min}$ at $90{ }^{\circ} \mathrm{C}$ had improved thermal stability when further heated $\left(90{ }^{\circ} \mathrm{C}\right.$ for $\left.5 \mathrm{~min}\right)$ in solutions that contained $0-108 \mathrm{mM}$ added $\mathrm{NaCl}$ due to their altered aggregate shape and higher charge, which resulted in final aggregates that were smaller and less dense than in previously untreated WPI. when further heated with added $\mathrm{NaCl}$ and large protein aggregates formed $(\sim 10-50 \mu \mathrm{m}$; Fig 6, 4B and 5B); turbidity was not measured in the WPH solutions that showed precipitation. 
390 Precipitation of the proteins/peptides in those WPH solutions is likely due to the exposure of

391 hydrophobic groups during enzymatic hydrolysis of the protein or the presence of more ionic

392 groups in the WPH solutions due to base addition for neutralisation during production of the

393 hydrolysed ingredient compared with the WPI (Adler-Nissen, 1986).

394 Solutions of WPI-MD17 or WPH-MD17 conjugates (i.e., previously heated for $8 \mathrm{~h}$ at

$39590{ }^{\circ} \mathrm{C}$ at an initial of $\mathrm{pH}$ 8.2) which had $40 \mathrm{mM} \mathrm{NaCl}$ added and were subsequently heated at

$39685{ }^{\circ} \mathrm{C}$ for 10 min increased in turbidity by just $2.1 \%$ and $0.5 \%$ compared with their respective

397 controls, and the protein aggregates present remained small $(<\sim 1 \mu \mathrm{m}$; Fig 6. 3B and 6B). It is

398 clear from these results that covalent attachment of the bulky hydrophilic MD to whey

399 proteins molecules through Maillard-induced conjugation greatly enhanced stability of whey

400 protein/peptide solutions when subsequently thermally treated in the presence of $\mathrm{NaCl}$. The

401 improvement in thermal stability of whey protein following conjugation with MD is most

402 likely due to enhanced steric hindrance due to the attachment of carbohydrate side chains

403 helping to prevent further heat-induced destabilisation, even in the presence of $\mathrm{NaCl}$.

404

405 4. Conclusion

406

407

This study showed that the physical state of whey protein molecules (i.e., intact or hydrolysed) had a considerable impact on the rate and extent of protein-carbohydrate

409 conjugation. Conjugation of intact and hydrolysed whey proteins with maltodextrin was

410 achieved by heating solutions at an initial $\mathrm{pH} 8.2$, at $90{ }^{\circ} \mathrm{C}$ for $8 \mathrm{~h}$. Low levels of hydrolysis

411 of the whey protein molecules resulted in an increase in the rate and extent of conjugation of

412 the whey protein with maltodextrin, with limited associated development of colour and

413 advanced Maillard products. Intact and hydrolysed whey protein-maltodextrin conjugate

414 solutions had significantly $(P<0.05)$ increased protein solubility in the $\mathrm{pH}$ range $4-5$ and the 
415 thermal stability (in an added salt environment) was superior to those of the unheated or

416 heated control solutions. Conjugation with maltodextrin provides a potential method to

417 enhance the functionality of hydrolysed whey proteins in food applications. Further

418 investigation of such protein-carbohydrate conjugates in formulated food applications is

419 required.

420

421 Acknowledgements

422

423

The authors would like to acknowledge Sandeep Kanniganti and Dr Andre Brodkorb

at Teagasc Food Research Centre, Moorepark, Fermoy, Cork, Ireland for their assistance with

the size exclusion chromatography analysis. The authors are grateful to our colleagues, Kamil

Drapala for the help with acquiring confocal micrographs at the Bio-Sciences Imaging Centre

427

(Department of Anatomy \& Neuroscience Imaging Centre, BioSciences Institute, University

College Cork) and Shane Crowley for the helpful technical discussions on the manuscript.

This research was financially supported by the Food Institutional Research Measure (FIRM)

initiative of the Irish Department of Agriculture, Food and the Marine (project number 10/RD/OptiHydro/UCC/702).

432

References

Adler-Nissen, J. (1986). Enzymic hydrolysis offood proteins. New York, NY, USA: Elsevier Applied Science Publishers Ltd.

Adjonu, R., Doran, G., Torley, P., \& Agboola, S. (2013). Screening of whey protein isolate hydrolysates for their dual functionality: Influence of heat pre-treatment and enzyme specificity. Food Chemistry, 136, 1435-1443. 
440 Anand, K., Ward, G., Froehner, G., Brody, E., \& Schroeder, C. (2002). Recommendations for use as industry standard methods for characterization of whey protein hydrolysates. Bulletin-International Dairy Federation, 374, 70-74.

AOAC. (1995). Official methods of analysis (16th edn, Vol. 33, pp. 1-75). Arlington, VA, USA: Association of Official Analytical Chemists.

Berg, H. E., \& Van Boekel, M. A. J. S. (1994). Degradation of lactose during heating of milk. 1. Reaction pathways. Netherlands Milk and Dairy Journal, 48, 157-175.

Calabrese, M. G., Mamone, G., Caira, S., Ferranti, P., \& Addeo, F. (2009). Quantitation of lysinoalanine in dairy products by liquid chromatography-mass spectrometry with selective ion monitoring. Food Chemistry, 116, 799-805.

Chevalier, F., Chobert, J. M., Popineau, Y., Nicolas, M. G., \& Haertlé, T. (2001). Improvement of functional properties of $\beta$-lactoglobulin glycated through the Maillard reaction is related to the nature of the sugar. International Dairy Journal, 11, 145152.

Chobert, J. M., Bertrand-Harb, C., \& Nicolas, M. G. (1988). Solubility and emulsifying properties of caseins and whey proteins modified enzymically by trypsin. Journal of Agricultural and Food Chemistry, 36, 883-892.

Clemente, A. (2000). Enzymatic protein hydrolysates in human nutrition. Trends in Food Science and Technology, 11, 254-262.

Creusot, N., \& Gruppen, H. (2007a). Enzyme-induced aggregation and gelation of proteins. Biotechnology Advances, 25, 597-601.

461 Creusot, N., \& Gruppen, H. (2007b). Hydrolysis of whey protein isolate with Bacillus 462 licheniformis protease: fractionation and identification of aggregating peptides. Journal of Agricultural and Food Chemistry, 55, 9241-9250. 
464 Dairymark. (2012). Whey protein: A strategic review of opportunities and applications. Retrieved http://www.dairymark.com/pdf/whey.pdf

466

467

468

469

470

471

472

473

474

475

476

477

478

479

480

481

482

483

484

485

486

487

Da Silva Pinto, M., Bouhallab, S., De Carvalho, A. F., Henry, G., Putaux, J. L., \& Leonil, J. (2011). Glucose slows down the heat-induced aggregation of $\beta$-lactoglobulin at neutral pH. Journal of Agricultural and Food Chemistry, 60, 214-219.

Davidov-Pardo, G., Joye, I. J., Espinal-Ruiz, M., \& McClements, D. J. (2015). Effect of Maillard conjugates on the physical stability of zein nanoparticles prepared by liquid antisolvent coprecipitation. Journal of Agricultural and Food Chemistry, 63, $8510-8518$.

Drapala, K. P., Auty, M. A., Mulvihill, D. M., \& O'Mahony, J. A. (2015). Influence of lecithin on the processing stability of model whey protein hydrolysate-based infant formula emulsions. International Journal of Dairy Technology, 68, 322-333.

Foegeding, E. A., Davis, J. P., Doucet, D., \& McGuffey, M. K. (2002). Advances in modifying and understanding whey protein functionality. Trends in Food Science and Technology, 13, 151-159.

Friedman, M. (1996). Food browning and its prevention: an overview. Journal of Agricultural and Food Chemistry, 44, 631-653.

Hodge, J. E. (1953). Dehydrated foods, chemistry of browning reactions in model systems. Journal of Agricultural and Food Chemistry, 1, 928-943.

Indyk, H. E., Edwards, M. J., \& Woollard, D. C. (1996). High performance liquid chromatographic analysis of lactose-hydrolysed milk. Food Chemistry, 57, 575-580.

Ju, Z. Y., Otte, J., Madsen, J. S., \& Qvist, K. B. (1995). Effects of limited proteolysis on gelation and gel properties of whey protein isolate. Journal of Dairy Science, 78, 2119-2128. 
Liu, G., \& Zhong, Q. (2015). High temperature-short time glycation to improve heat stability of whey protein and reduce color formation. Food Hydrocolloids, 44, 453-460.

Liu, J., Ru, Q., \& Ding, Y. (2012). Glycation a promising method for food protein modification: physicochemical properties and structure, a review. Food Research International, 49, 170-183.

Martins, S. I. F. S., Jongen, W. M. F., \& Van Boekel, M. A. J. S. (2000). A review of Maillard reaction in food and implications to kinetic modelling. Trends in Food Science and Technology, 11, 364-373.

Martinez-Alvarenga, M. S., Martinez-Rodriguez, E. Y., Garcia-Amezquita, L. E., Olivas, G. I., Zamudio-Flores, P. B., Acosta-Muniz, C. H., et al. (2014). Effect of Maillard reaction conditions on the degree of glycation and functional properties of whey protein isolate-Maltodextrin conjugates. Food Hydrocolloids, 38, 110-118.

Mulcahy, E. M., Mulvihill, D. M., \& O'Mahony, J. A. (2016). Physicochemical properties of 501 whey protein conjugated with starch hydrolysis products of different dextrose equivalent values. International Dairy Journal, 53, 20-28.

Nielsen, P. M., Petersen, D., \& Dambmann, C. (2001). Improved method for determining food protein degree of hydrolysis. Journal of Food Science, 66, 642-646.

Nielsen, P. M (1997). Functionality of protein hydrolysates. In S. Damodaran \& A. Paraf, (Eds), Food proteins and their applications, (pp. 443-472). New York, NY, USA: Marcel Dekker, Inc.

508 Nnanna, I. A., \& Wu, C. (2007) Dairy protein hydrolysates. In Y. H. Hui, (Ed), Handbook of food products manufacturing (pp. 537-556). New Jersey, NJ, USA: John Wiley and Sons Inc. 
511 O’Loughlin, I. B., Murray, B. A., Brodkorb, A., FitzGerald, R. J., Robinson, A. A., Holton, T. A., et al. (2013). Whey protein isolate polydispersity affects enzymatic hydrolysis outcomes. Food Chemistry, 141, 2334-2342.

514 O’Regan, J, \& Mulvihill, D. M. (2013). Preparation, characterisation and selected functional properties of hydrolysed sodium caseinate-maltodextrin conjugate. International Journal of Dairy Technology, 66, 333-345.

Panyam, D., \& Kilara, A. (1996). Enhancing the functionality of food proteins by enzymatic modification. Trends in Food Science and Technology, 7, 120-125.

Pellegrino, L., Van Boekel, M. A. J. S., Gruppen, H., Resmini, P., \& Pagani, M. A. (1999). Heat-induced aggregation and covalent linkages in $\beta$-casein model systems. International Dairy Journal, 9, 255-260.

Ryan, K. N., Vardhanabhuti, B., Jaramillo, D. P., van Zanten, J. H., Coupland, J. N., \& Foegeding, E. A. (2012). Stability and mechanism of whey protein soluble aggregates thermally treated with salts. Food Hydrocolloids, 27, 411-420.

Saint-Sauveur, D., Gauthier, S. F., Boutin, Y., \& Montoni, A. (2008). Immunomodulating properties of a whey protein isolate, its enzymatic digest and peptide fractions. International Dairy Journal, 18, 260-270.

Sharma, R., Rajput, Y. S., \& Mann, B. (2013). Chemical and functional properties of glycomacropeptide (GMP) and its role in the detection of cheese whey adulteration in milk: a review. Dairy Science and Technology, 93, 21-43.

Singh, A. M., \& Dalgleish, D. G. (1998). The emulsifying properties of hydrolyzates of whey proteins. Journal of Dairy Science, 81, 918-924. Dairy Journal, 18, 695-704. 
535 Wijayanti, H. B., Bansal, N., \& Deeth, H. C. (2014). Stability of whey proteins during thermal processing: A review. Comprehensive Reviews in Food Science and Food Safety, 13, 1235-1251. 


\section{Table 1}

555 Composition and degree of hydrolysis of the whey protein isolate (WPI) and whey protein

556 hydrolysate (WPH). ${ }^{a}$

\begin{tabular}{lll}
\hline Composition & WPI & WPH \\
\hline Protein (total) & $87.2 \pm 0.9$ & $83.7 \pm 0558$ \\
Lactose & $0.4 \pm 0.02$ & $2.8 \pm 0.559$ \\
Ash & $2.8 \pm 0.1$ & $2.9 \pm 0.1$ \\
Degree of hydrolysis & - & $9.3 \pm 0.560$ \\
Insoluble protein & $0.0 \pm 0.0$ & $1.8 \pm 0.961$ \\
$>20 \mathrm{kDa}$ & $28.0 \pm 3.4$ & $12.0 \pm 1.6$ \\
$10-20 \mathrm{kDa}$ & $50.5 \pm 3.7$ & $24.2 \pm 8.8$ \\
$5-10 \mathrm{kDa}$ & $4.9 \pm 0.2$ & $9.5 \pm 1.9$ \\
$2-5 \mathrm{kDa}$ & $15.6 \pm 0.3$ & $11.9 \pm 1.6$ \\
$0-2 \mathrm{kDa}$ & $0.9 \pm 0.1$ & $40.5 \pm 25.63$ \\
\hline
\end{tabular}

564

$565{ }^{\text {a }}$ Values are means \pm standard deviation of data from three independent trials. Values for

566 protein, lactose, ash are a percentage on a w/w basis; degree of hydrolysis is the number of

567 peptide bonds cleaved expressed as a percentage of the original number of peptide bonds;

568 values for insoluble protein and different molecular mass ranges are percentages of total

569 protein.

570 


\section{Figure legends}

Fig. 1. Concentration of available amino groups in whey protein isolate (WPI), whey protein hydrolysate (WPH) and WPI/WPH-maltodextrin (MD17) solutions heated at an initial pH of 8.2 at $90{ }^{\circ} \mathrm{C}$ for up to $24 \mathrm{~h}$, expressed as a percentage of the respective unheated control:

$\triangle$ WPI; $\bigcirc$, WPH; $\boldsymbol{\Delta}$, WPI-MD17; $\bullet$,WPH-MD17. Values are presented as mean \pm standard deviation of data from three independent trials.

Fig. 2. pH of whey protein isolate (WPI), whey protein hydrolysate (WPH) and WPI/WPHmaltodextrin (MD17) solutions heated at an initial $\mathrm{pH}$ of 8.2 at $90{ }^{\circ} \mathrm{C}$ for up to $24 \mathrm{~h}: \triangle, \mathrm{WPI}$; O, WPH; $\boldsymbol{\Delta}$, WPI-MD17; $\boldsymbol{0}$, WPH-MD17. Values are presented as mean \pm standard deviation of data from three independent trials.

Fig. 3. Photographic image of whey protein isolate (WPI), whey protein hydrolysate (WPH) and WPI/WPH-maltodextrin (MD17) solutions heated at an initial $\mathrm{pH}$ of 8.2 at $90{ }^{\circ} \mathrm{C}$ for up to $24 \mathrm{~h}$

Fig. 4. Fluorescence of advanced Maillard products, expressed in relative fluorescence units (RFU) per gram of protein, in the $\mathrm{pH} 4$.6-soluble fraction of whey protein isolate (WPI), whey protein hydrolysate (WPH) and WPI/WPH-maltodextrin (MD17) solutions heated at an initial $\mathrm{pH}$ of 8.2 at $90{ }^{\circ} \mathrm{C}$ for up to $24 \mathrm{~h}$ : $\triangle$,WPI; $\bigcirc, \mathrm{WPH} ; \boldsymbol{\Delta}$, WPI-MD17; $\boldsymbol{\circ}$, WPHMD17. Values are presented as mean \pm standard deviation of data from three independent trials. 
Fig. 5. Protein solubility as a function of $\mathrm{pH}$ for whey protein isolate (WPI), whey protein hydrolysate (WPH) and WPI/WPH-maltodextrin (MD17) solutions unheated (- - -) or heated (一) at an initial $\mathrm{pH}$ of 8.2 at $90{ }^{\circ} \mathrm{C}$ for $8 \mathrm{~h}$ : A, WPI ( $\bigcirc$ or $\bigcirc$ ) and WPI-MD17 ( $\square$ or $\square$ ); B, WPH $(\diamond$ or $\diamond)$ and WPH-MD17 ( $\triangle$ or $\boldsymbol{\Delta})$. Values are presented as mean \pm standard deviation of data from three independent trials.

Fig. 6. Photographs and confocal laser scanning microscopy images of (1 and 2) WPI, (3) WPI-MD17, (4 and 5) WPH and (6) WPH-MD17. The solutions contained 2.5\% protein, at $\mathrm{pH}$ 6.8, before (A) and after (B) heating at $85^{\circ} \mathrm{C}$ for $10 \mathrm{~min}$; all solutions contained $40 \mathrm{~mm}$ added $\mathrm{NaCl}$. Photographs labelled with 1 and 4 received no prior heat treatment and 2, 3, 5 and 6 were previously heated at $90{ }^{\circ} \mathrm{C}$ for $8 \mathrm{~h}$ at an initial $\mathrm{pH}$ of 8.2 ; solutions labelled (A) are the respective controls for the sample set and solutions marked with * gelled/precipitated. Micrographs present distribution of protein (red) in different solutions. Scale bar (bottom right $)=50 \mu \mathrm{m}$ 


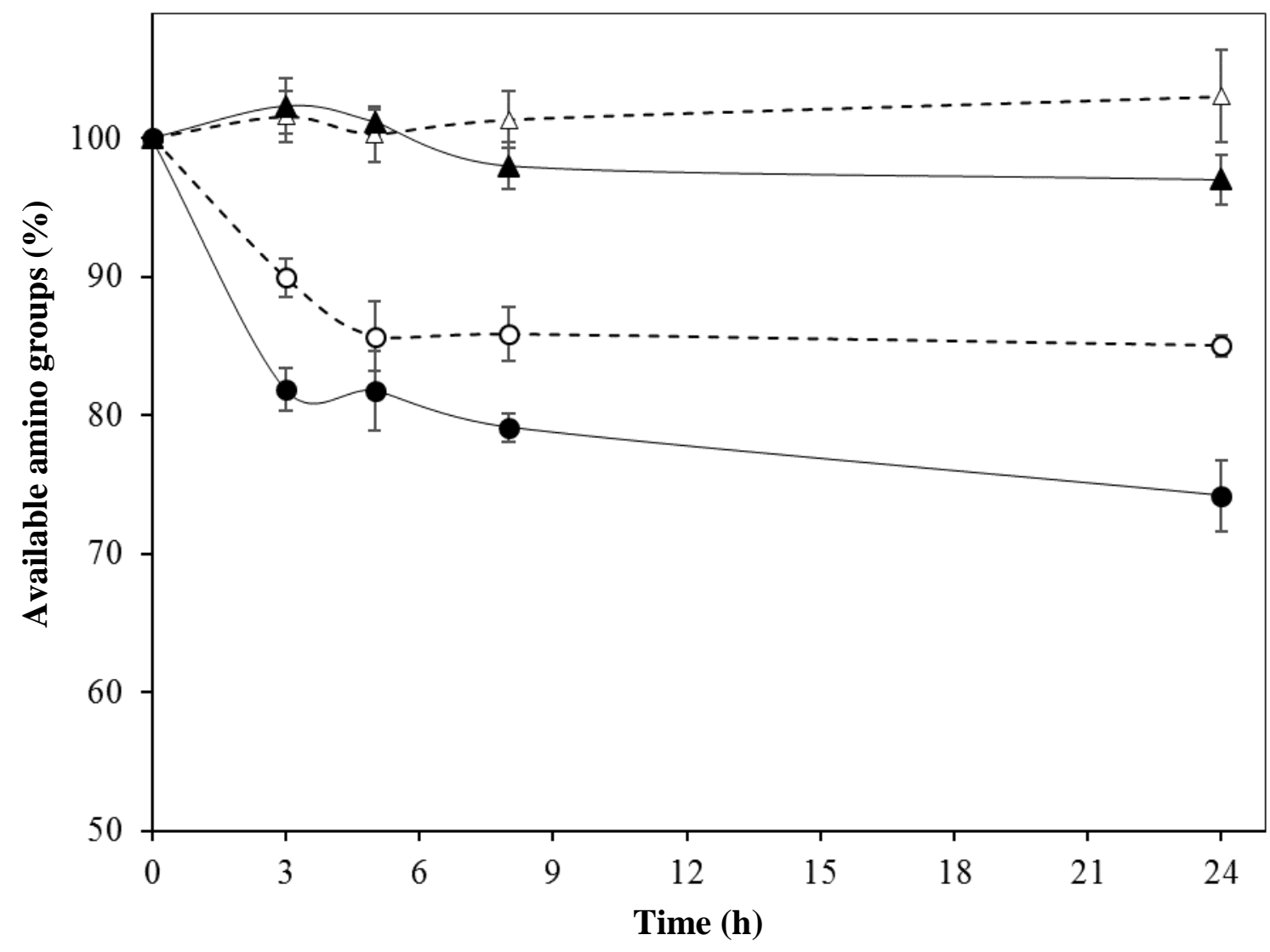

518

$519 \quad$ Fig. 1.

520 


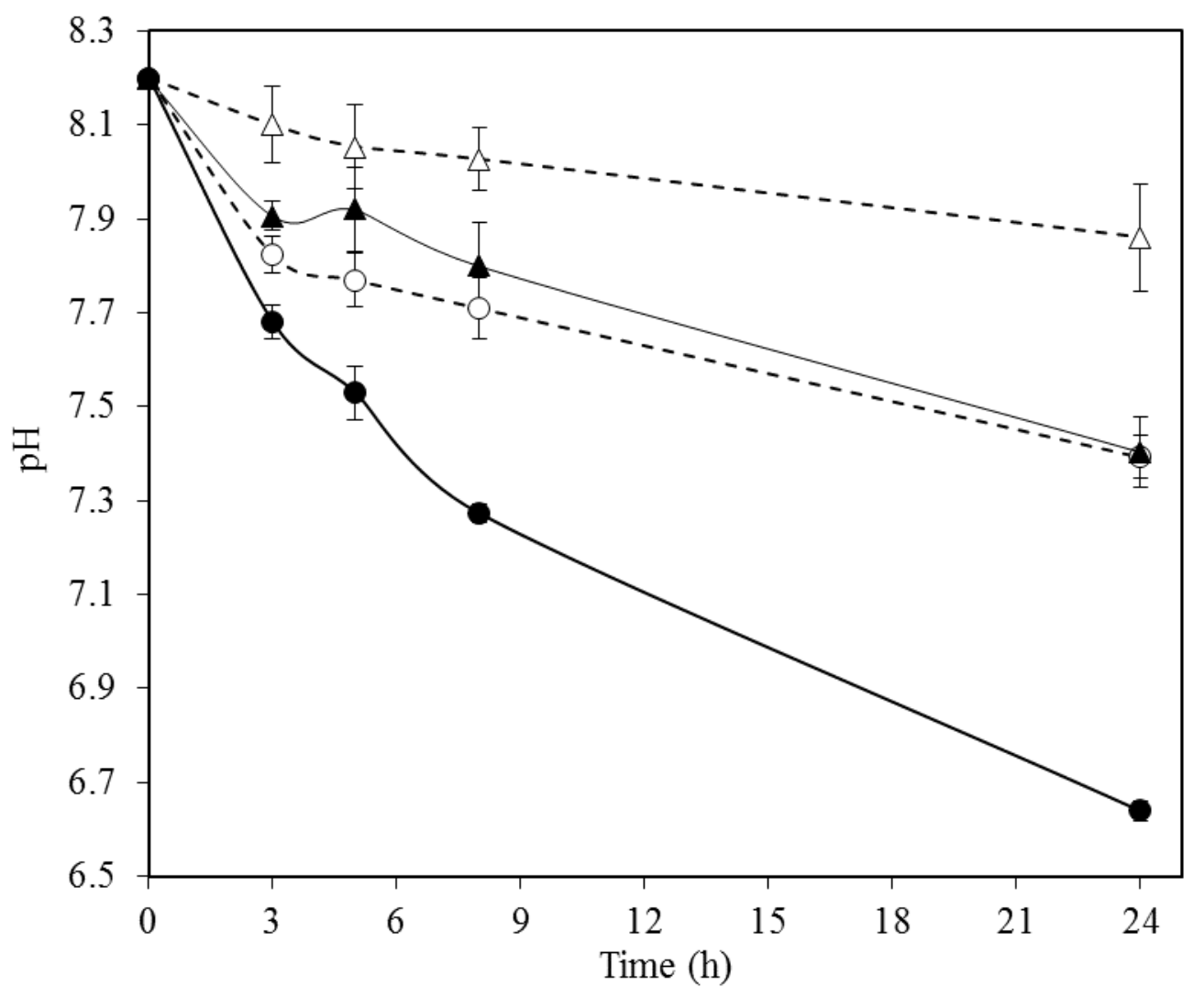

522

523 Fig. 2.

524

525 


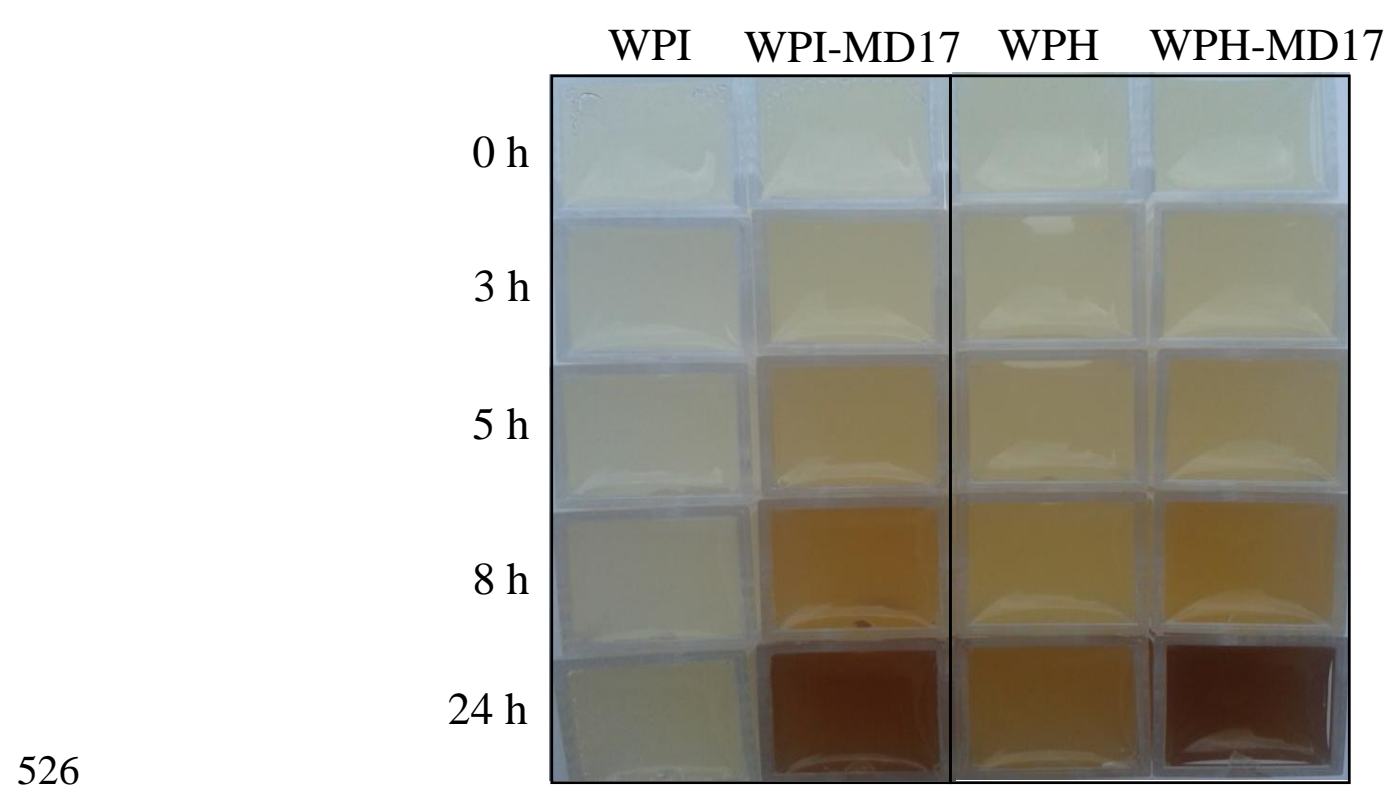

$527 \quad$ Fig. 3.

528 
530

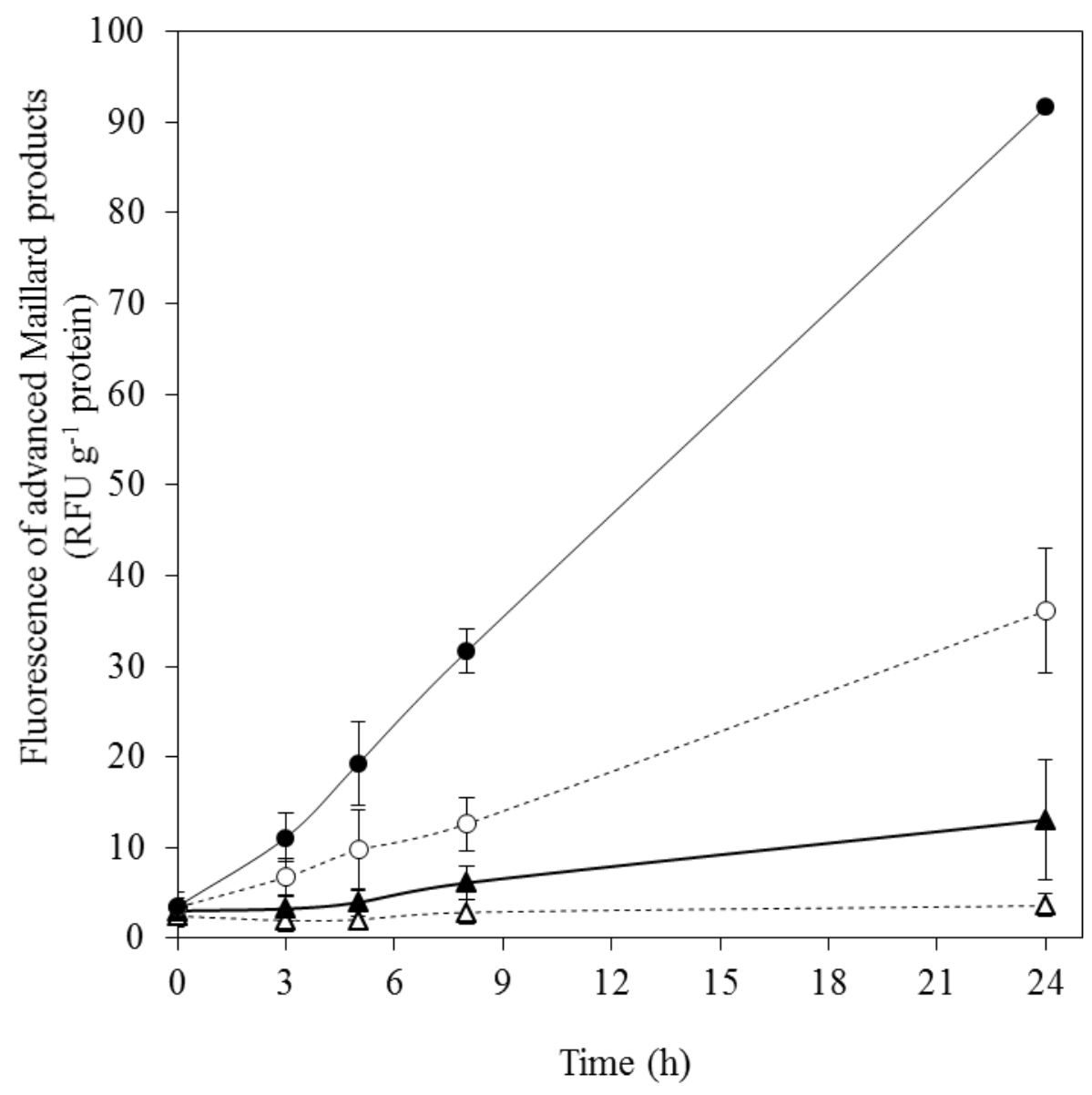

531

$532 \quad$ Fig. 4. 


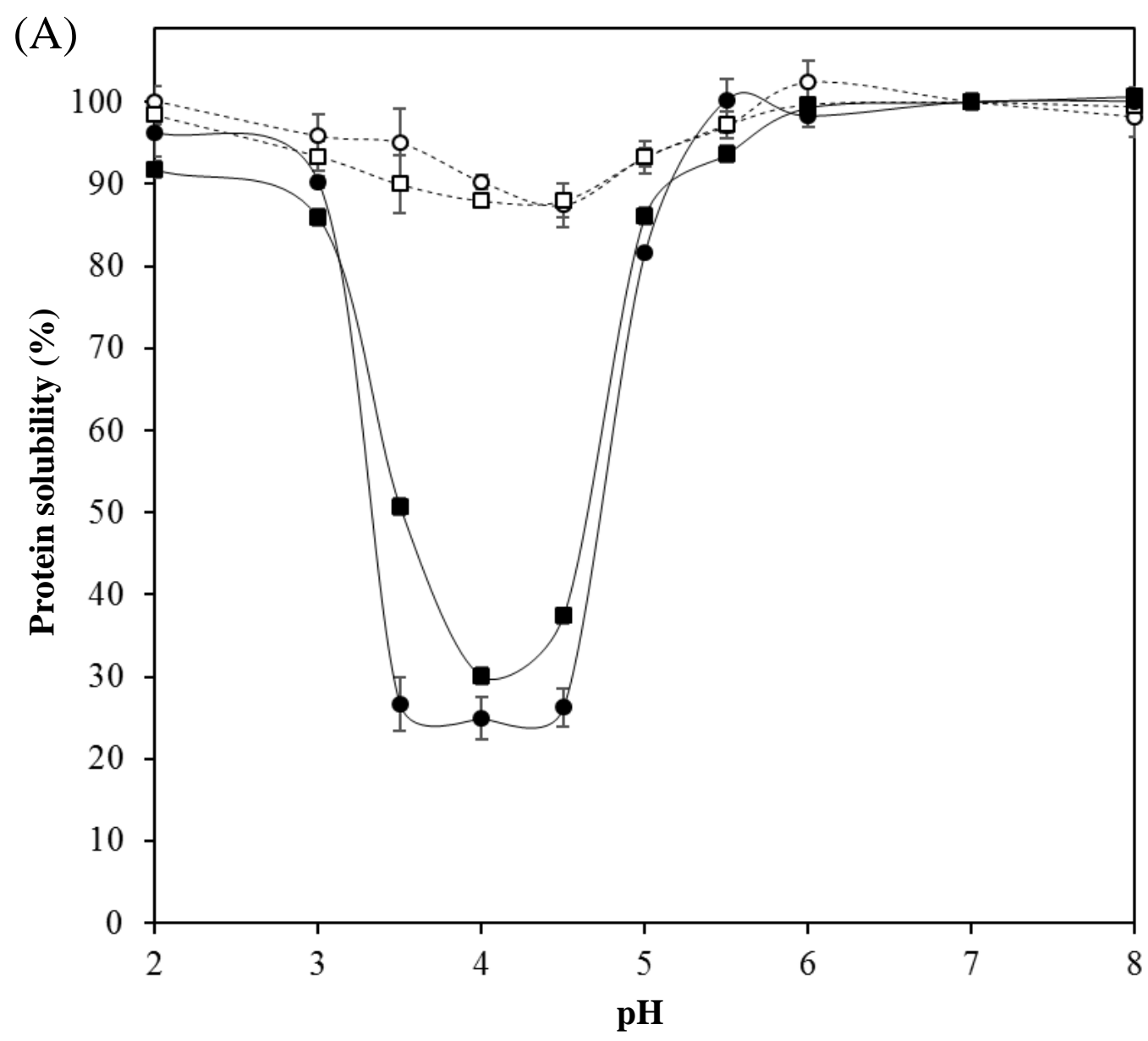

533

534 Fig. 5A.

535 


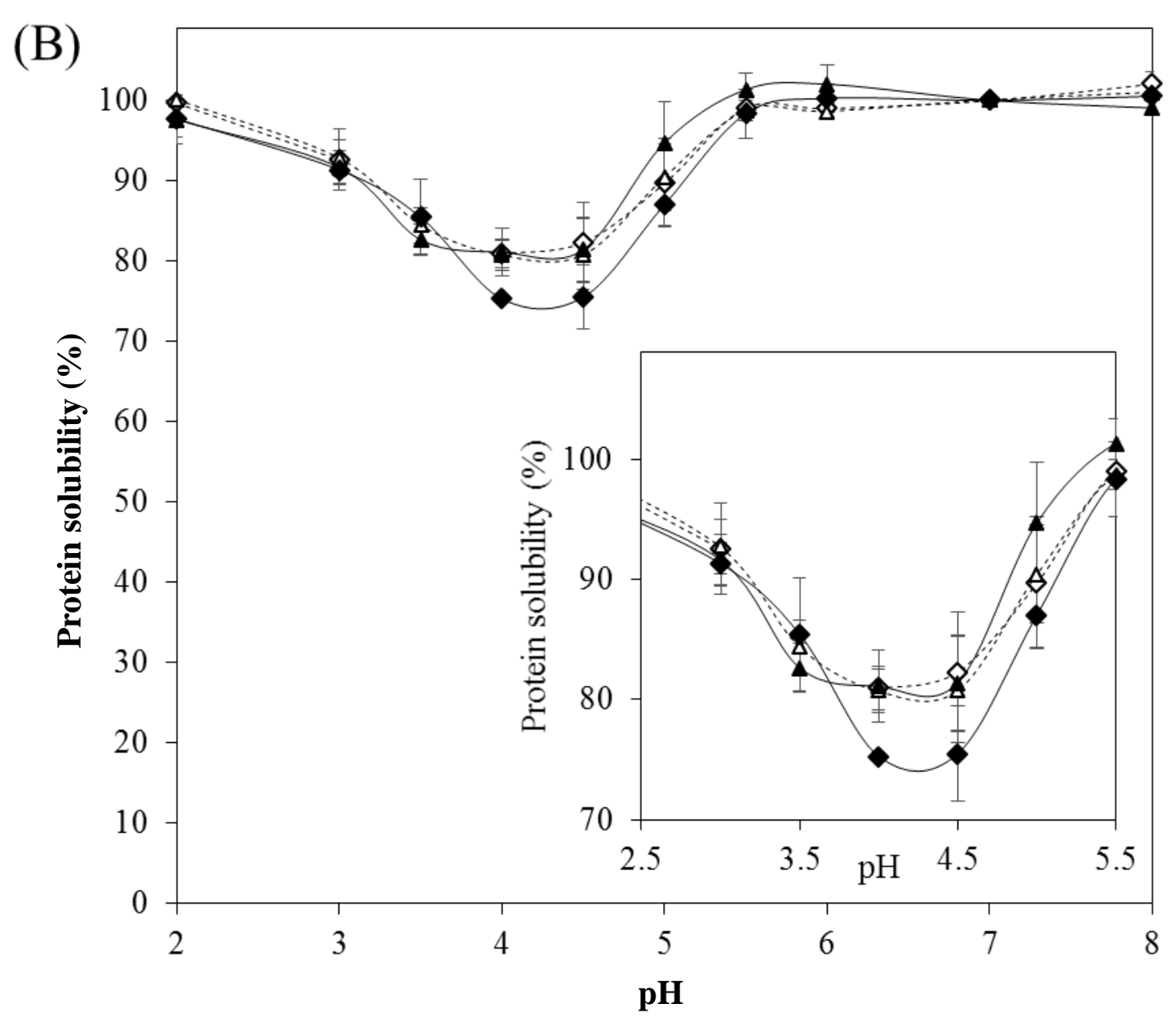

537

$538 \quad$ Fig. 5B. 


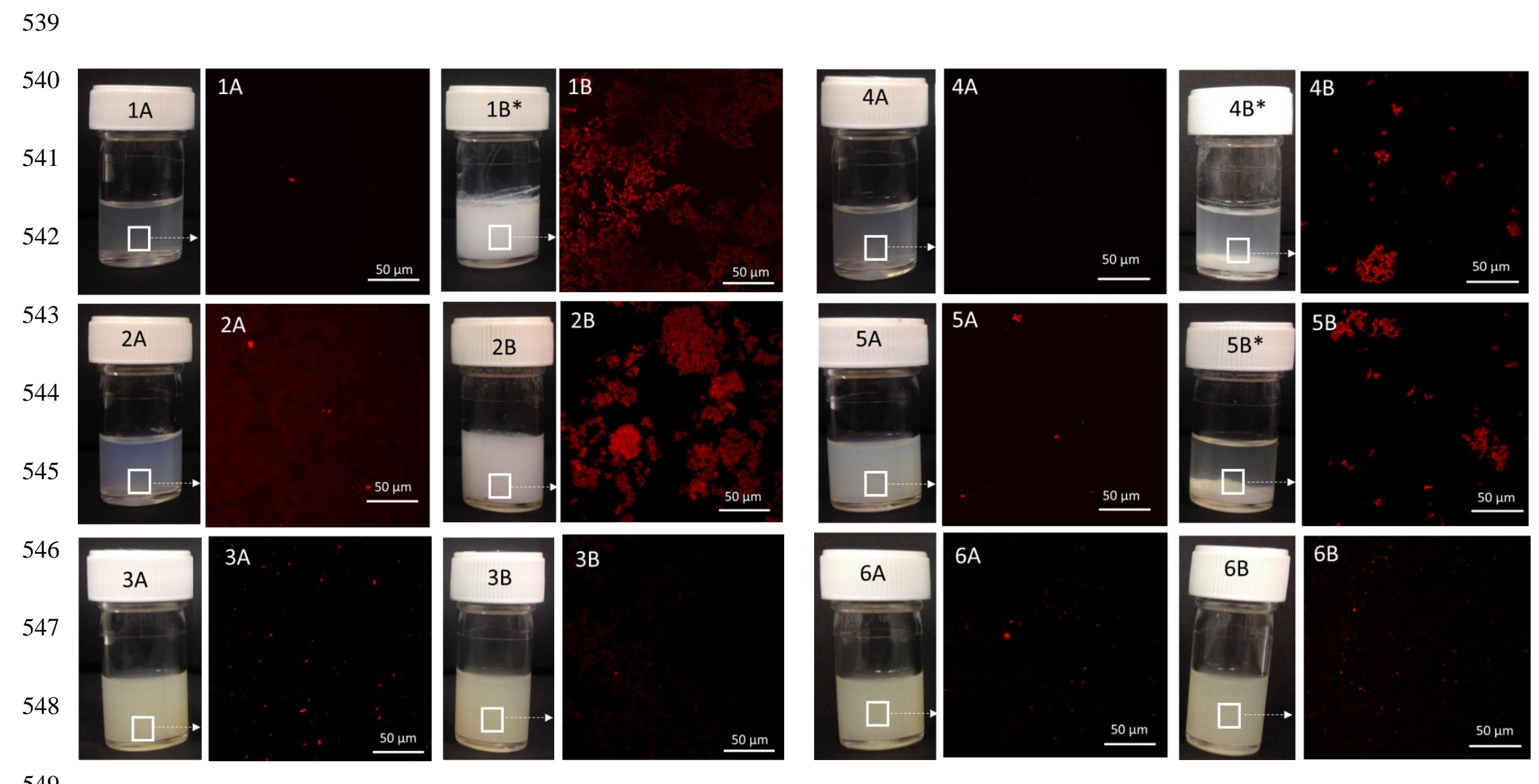

$550 \quad$ Fig. 6. 
Figures $3 \& 6$ for print

513

514

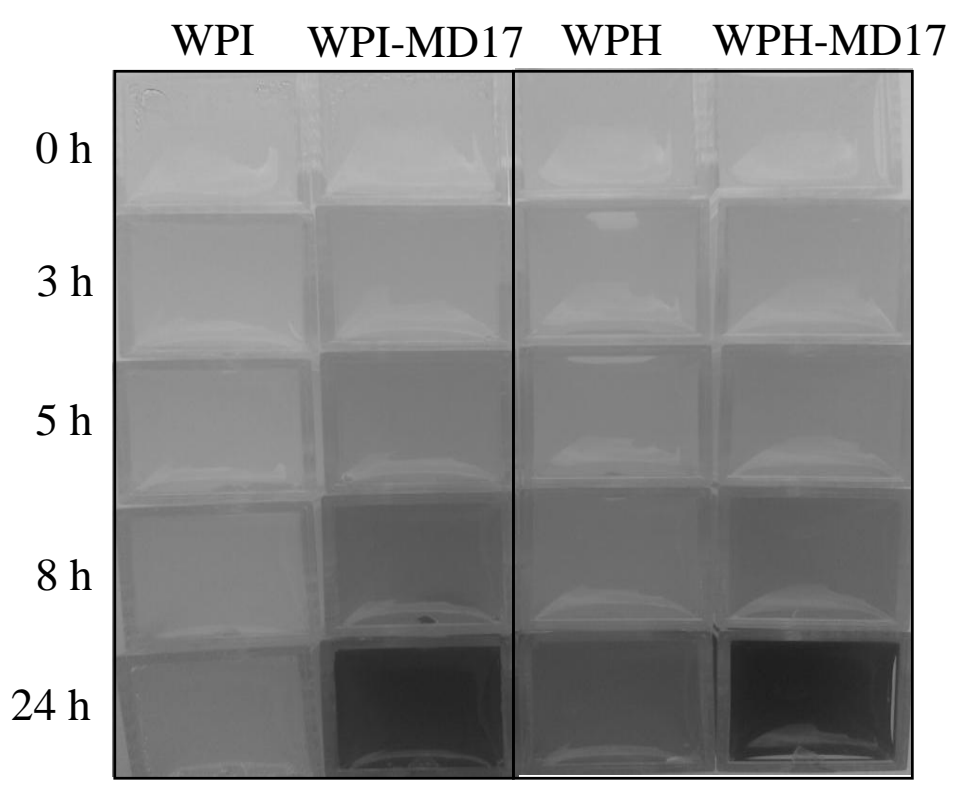

$515 \quad$ Fig. 3. 

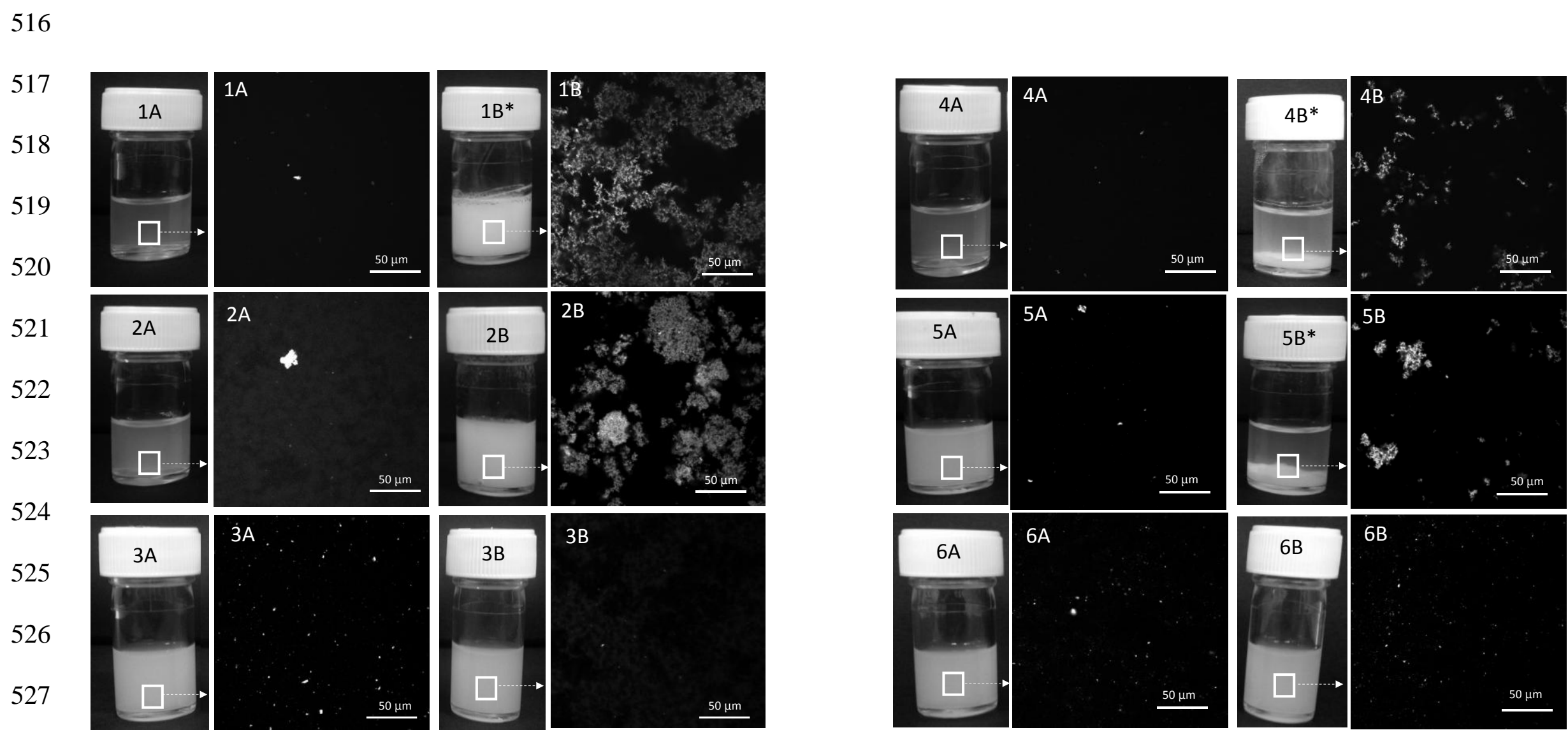

528

Fig. 6 